\title{
Impact of monovalent cations on soil structure. Part II. Results of two Swiss soils
}

\author{
Elham Farahani ${ }^{1}$, Hojat Emami ${ }^{1}$, and Thomas Keller ${ }^{2,3 *}$ \\ ${ }^{1}$ Faculty of Agriculture, Department of Soil Science, Ferdowsi University of Mashhad, 9177948978 Mashhad, Iran \\ ${ }^{2}$ Agroscope, Department of Agroecology and Environment, 191, 8046 Zürich, Zürich, Switzerland \\ ${ }^{3}$ Department of Soil and Environment, Swedish University of Agricultural Sciences, Box 7014, 75007 Uppsala, Sweden
}

Received July 21, 2017; accepted December 6, 2017

\begin{abstract}
A bstract. In this study, we investigated the impact of adding solutions with different potassium and sodium concentrations on dispersible clay, water retention characteristics, air permeability, and soil shrinkage behaviour using two agricultural soils from Switzerland with different clay content but similar organic carbon to clay ratio. Three different solutions (including only $\mathrm{Na}$, only $\mathrm{K}$, and the combination of both) were added to soil samples at three different cation ratio of soil structural stability levels, and the soil samples were incubated for one month. Our findings showed that the amount of readily dispersible clay increased with increasing $\mathrm{Na}$ concentrations and with increasing cation ratio of soil structural stability. The treatment with the maximum $\mathrm{Na}$ concentration resulted in the highest water retention and in the lowest shrinkage capacity. This was was associated with high amounts of readily dispersible clay. Air permeability generally increased during incubation due to moderate wetting and drying cycles, but the increase was negatively correlated with readily dispersible clay. Readily dispersible clay decreased with increasing $\mathrm{K}$, while readily dispersible clay increased with increasing $\mathrm{K}$ in Iranian soil (Part I of our study). This can be attributed to the different clay mineralogy of the studied soils (muscovite in Part I and illite in Part II).

Keyw ord s: air-permeability, sodium, potassium, soil shrinkage, specific volume, turbidity
\end{abstract}

\section{INTRODUCTION}

Salt-affected soils are found in most climatic zones of the world, although salinisation problems mainly occur in arid and semi-arid regions. The extent and nature of salt problems can have various sources. It can originate from mineral weathering, stored salts, aeolian salinity, rainfall, and irrigation with saline/sodic water. Salinisation is a complicated process involving seasonal water and salts movement in soils, and interactions with groundwater.

*Corresponding author e-mail: thomas.keller@agroscope.admin.ch
Sodium salts are prevailing in many salt-affected soils of the world (Rengasamy, 2006). Monovalent cations, such as sodium $(\mathrm{Na})$ and potassium $(\mathrm{K})$ can create clay dispersion and swelling. Swelling takes place when the concentration of monovalent cations is high, while dispersion will occur in soils with low cation concentration (Shainberg and Letey, 1984; Sumner, 1993). Dispersion (also termed deflocculation) is the consequence of an increase in the thickness of the diffuse double layer, accompanied by a decrease in the attractive forces between clay particles (Menneer et al., 2001). Swelling and dispersion of clays has significant (mostly negative) effects on soil structure and associated soil functions (fluid-transport functions) (Chaudhari and Somawanshi, 2004): swelling reduces soil pore sizes and dispersed clay may clog soil pores (Frenkel and Rhoades, 1978).

Soil structure is central for many ecosystem services, including (agricultural) productivity and flood control. Soil structure has two important characteristics (Kay, 1990): form, i.e. the geometrical arrangement of soil particles and pores, and stability, i.e. resistance against stress. A range of soil functions are largely governed by soil structure, such as the soil fluid transport capability that regulates the soil gas (aeration) and water balance (infiltration). Such functions can, therefore, be used as indicators of the quality of soil structure and of soil-structure changes caused by soil management practices (tillage, crop rotation, and fertilisation), soil compaction or salinisation (Ball, 1981; Blackwell et al., 1990; Iversen et al., 2001). Fluid transport properties are typically more sensitive to modifications of soil structure than, for example, water retention or porosity,

(C) 2018 Institute of Agrophysics, Polish Academy of Sciences 
because transport functions are not only affected by pore size (distribution) but also by pore connectivity, continuity and tortuosity. The shrinkage characteristics of soil could contain information on both porosity and structural stability (Schäffer et al., 2013). Shrinkage curves (soil volume as a function of soil moisture content; Braudeau et al., 1999) have therefore been used to assess the structural quality of soils (Johannes et al., 2017) and to quantify soil management and compaction effects on soil structure (Schäffer et al., 2008; 2013). Sou/Dakouré et al. (2013) used shrinkage curves to assess the impact of irrigation water containing different concentrations of salts on the physical quality of a sandy loam soil in Burkina Faso.

Most investigations on the impact of salinity on clay dispersion, soil structure and stability have concentrated on the effect of highly exchangeable $\mathrm{Na}$ (Rengasamy, 2002). Exchangeable $\mathrm{K}$ can create similar effects as $\mathrm{Na}$ on soil structure, but it has received less attention than $\mathrm{Na}$ because concentrations of $\mathrm{K}$ are typically low in salt-affected soils (Rengasamy and Marchuk, 2011). K is one of the most important nutrients for plant growth and is usually added into soils as a fertiliser. The impact of exchangeable $\mathrm{K}$ on soil structure has been reported in the literature as being equal or less negative than the impact of $\mathrm{Na}$ (Chen et al., 1983; El Swaify et al., 1970). However, K in the exchange complex has been shown to affect clay dispersion as well, even at small amounts of exchangeable $\mathrm{Na}$ (Arienzo et al., 2009; Emami et al., 2014; Rengasamy, 2006; Robbins, 1984; Smiles, 2006; Subba Rao and Rao, 1996).

The objective of the present study was to investigate the impact of $\mathrm{K}$ and $\mathrm{Na}$ on soil structure and its stability for two soils with contrasting texture from northern Switzerland. The soil samples were incubated for one month using three types of solutions ( $\mathrm{Na}$ only, $\mathrm{K}$ only, and a solution with both $\mathrm{Na}$ and $\mathrm{K}$ ) with different cationic concentrations. The amount of readily dispersible clay (RDC), air-permeability $\left(k_{a}\right)$ and soil shrinkage characteristics were measured after one-month incubation. We then discuss the role of clay mineralogy behind the impact of $\mathrm{K}$ on soil structure, considering the results of the present study and the results of our study of soil from Iran (Part I of the series of papers).

\section{MATERIAL AND METHODS}

Soil samples were collected from the 0-0.3 m depth of two agricultural fields located at the Agroscope Research Institute in Zürich, northern Switzerland $\left(47.3^{\circ} \mathrm{N}\right.$ latitude, $8.5^{\circ} \mathrm{E}$ longitude and $408 \mathrm{~m}$ a.s.l. altitude). We selected two soils with different clay content, but with a similar ratio of organic carbon (OC) to clay content: a clay soil with $45 \%$ clay, below referred to as ' $\mathrm{cl}$ ', and a silty loam with $22 \%$ clay, below referred to as 'si l'. Both soils had an OC/ Clay ratio of $c$. 0.07. The basic characteristics of the soils are presented in Table 1. Soil texture was determined using the pipette method (Gee and Bauder, 1986), and soil organic carbon was measured using the wet oxidation method (Walkley and Black, 1934). Electrical conductivity (EC) and $\mathrm{pH}$ were determined using soil water ratios of 1:2.5 and 1:3.3, respectively (Richards, 1954). Cation exchange capacity $(C E C)$ and the concentration of exchangeable cations were determined by extracting the soils with a 0.1 $\mathrm{M} \mathrm{BaCl}_{2}$ solution, containing $0.03 \mathrm{M}$ Triethanolamine and $0.015 \mathrm{M} \mathrm{HCl}$, and with the $\mathrm{pH}$ adjusted to 8.1. $\mathrm{Ca}$ and $\mathrm{Mg}$ were measured by F-AAS (Flame-atomic absorption spectroscopy), and $\mathrm{K}$ and $\mathrm{Na}$ were measured by F-AES (Flame-atomic emission spectroscopy) (Rouessac and Rouessac, 2007).

In order to remove stones and clods, the soils were sieved $(<10 \mathrm{~mm})$ without crashing, placed into cylinders ( $5 \mathrm{~cm}$ diameter, $5 \mathrm{~cm}$ height; $100 \mathrm{~cm}^{3}$ ), and prepared at a bulk density corresponding to a relative bulk density, $\mathrm{BD}_{\text {ref, }}$ of 0.7 . The relative bulk density is a measure of the soil compactness and allows comparisons across soil textures, and was defined here as the ratio of actual bulk density to the Proctor maximum density, where the latter was estimated according to Naderi-Boldaji et al. (2016). The bulk densities were 1.18 and $1.04 \mathrm{~g} \mathrm{~cm}^{-3}$ for the si 1 and cl soil, respectively.

The soil samples were incubated with salt solutions for one month. We considered three types of solutions: only $\mathrm{Na}$, only $\mathrm{K}$, and both $\mathrm{Na}$ and $\mathrm{K}$; and three levels of concentrations for each solution type with values for CROSS of 15,25 and 35 . This resulted in a total of 3 solution types $\times$ 3 concentration levels $=9$ treatments (Table 2). The same treatments were applied to both soils. The electrical conductivity (EC) of the solutions was calculated from total cation concentrations $(\mathrm{TCC})$ as $\mathrm{EC}\left(\mathrm{dS} \mathrm{m} \mathrm{m}^{-1}\right) \approx \mathrm{TCC}\left(\mathrm{mmol}_{\mathrm{c}}\right.$

T a b l e 1. Selected physical and chemical soil properties

\begin{tabular}{|c|c|c|c|c|c|c|c|c|c|c|c|c|c|}
\hline \multirow{2}{*}{$\begin{array}{l}\text { Soil } \\
\text { texture }\end{array}$} & Clay & Silt & Sand & $\mathrm{OC}$ & \multirow{2}{*}{$\begin{array}{l}\mathrm{OC} / \\
\text { Clay }\end{array}$} & \multirow{2}{*}{$\begin{array}{c}\mathrm{EC} \\
\left(\mu \mathrm{S} \mathrm{cm}^{-1}\right)\end{array}$} & \multirow{2}{*}{$\mathrm{pH}$} & $C E C$ & K & $\mathrm{Na}$ & $\mathrm{Ca}$ & $\mathrm{Mg}$ & \multirow{2}{*}{$\begin{array}{l}\text { Dominant } \\
\text { clay type* }\end{array}$} \\
\hline & \multicolumn{4}{|c|}{$(\%)$} & & & & \multicolumn{5}{|c|}{$\left(\mathrm{cmol}_{\mathrm{c}} \mathrm{kg}^{-1}\right)$} & \\
\hline Si 1 & 22.0 & 53.7 & 24.3 & 1.7 & 0.07 & 229 & 7.8 & 17.5 & 0.3 & 0.02 & 15.5 & 1.2 & Illite \\
\hline $\mathrm{cl}$ & 44.7 & 34.7 & 15.3 & 3.1 & 0.07 & 253 & 6.1 & 37.8 & 0.2 & 0.07 & 23.1 & 2.7 & Illite \\
\hline
\end{tabular}

OC - organic carbon content, EC - electrical conductivity, CEC - cation exchange capacity (*Peters, 1969). 
Table 2. Cation concentrations of the treatment solutions

\begin{tabular}{|c|c|c|c|c|c|c|}
\hline \multirow{2}{*}{ Treatment } & $\mathrm{K}$ & $\mathrm{Na}$ & $\mathrm{Ca}$ & $\mathrm{Mg}$ & \multirow{2}{*}{$\begin{array}{c}\mathrm{EC}_{\mathrm{tr}} \\
\left(\mathrm{dS} \mathrm{m}^{-1}\right)\end{array}$} & \multirow{2}{*}{$C^{2} O S S_{t r}$} \\
\hline & \multicolumn{4}{|c|}{$\left(\mathrm{mmol}_{\mathrm{c}} \mathrm{l}^{-1}\right)$} & & \\
\hline $\mathrm{Na}-1$ & 0 & 14 & 1 & 1 & 1.5 & 15 \\
\hline $\mathrm{Na}-2$ & 0 & 23 & 1 & 1 & 2.5 & 25 \\
\hline $\mathrm{Na}-3$ & 0 & 31 & 1 & 1 & 3.3 & 35 \\
\hline K-1 & 24 & 0 & 1 & 1 & 2.6 & 15 \\
\hline $\mathrm{K}-2$ & 40 & 0 & 1 & 1 & 4.2 & 25 \\
\hline K-3 & 56 & 0 & 1 & 1 & 5.8 & 35 \\
\hline$(\mathrm{Na}+\mathrm{K})-1$ & 12 & 7 & 1 & 1 & 2.0 & 15 \\
\hline$(\mathrm{Na}+\mathrm{K})-2$ & 20 & 11 & 1 & 1 & 3.3 & 25 \\
\hline$(\mathrm{Na}+\mathrm{K})-3$ & 28 & 16 & 1 & 1 & 4.6 & 35 \\
\hline Control & 0 & 0 & 0 & 0 & 0 & 0 \\
\hline
\end{tabular}

$\mathrm{EC}_{t r}$ - electrical conductivity of the treatment solution, $C R O S S_{t r}$ - cation ratio of soil structural stability of the treatment solution.

$\left.1^{-1}\right) / 10$. The range of $\mathrm{Na}$ concentrations was between 6.7 and $31.3 \mathrm{mmol}_{\mathrm{c}} \mathrm{l}^{-1}$, and the $\mathrm{K}$ concentrations were in the range of 11.9 to $55.9 \mathrm{mmol}_{\mathrm{c}} \mathrm{l}^{-1}$. Constant concentrations of $\mathrm{Ca}$ and $\mathrm{Mg}$ were considered at each CROSS level, as we did not aim to assess the impact of divalent cations on soil structure. The sum of the concentrations of $\mathrm{Ca}$ and $\mathrm{Mg}$ in the treatment solutions was larger than the swelling threshold concentration of $0.3 \mathrm{mmol} \mathrm{l}^{-1}$ defined by Quirk and Schofield (1955) for mixed solutions: 0.5 and $0.5 \mathrm{mmol} \mathrm{l}^{-1}$ for $\mathrm{CaCl}_{2}$ and $\mathrm{MgCl}_{2}$, respectively. To quantify the flocculation and dispersing power of our solutions on soil structure, we calculated the cation ratio of soil structural stability (CROSS) as (Rengasamy and Marchuk, 2011):

$$
\text { CROSS }_{\text {tr }}=\frac{\mathrm{Na}+0.56 \mathrm{~K}}{\sqrt{\frac{\mathrm{Ca}+0.6 \mathrm{Mg}}{2}}},
$$

where: the concentrations of cations are in $\mathrm{mmol}_{\mathrm{c}} \mathrm{l}^{-1}$ and the subscript ' $t r$ ' indicates 'treatment solution'.

The solutions were added to the soil samples by capillary rise from the bottom, thereby reaching water content close to saturation. Four replicates (i.e. four cylinders) per treatment were used. The soils in the cylinders were exposed to moderate drying and wetting cycles during the one month incubation. The drying process at room temperature $\left(20-25^{\circ} \mathrm{C}\right)$ continued only up to the water content corresponding to field capacity ( $100 \mathrm{hPa}$ matric suction), and this was ensured by monitoring the weight of the samples on a daily basis. The weight of each sample at $100 \mathrm{hPa}$ matric suction was measured before the start of the incuba- tion. The moderate drying also helped to avoid the creation of gaps between soil and cylinder walls. For the wetting, distilled water with a volume corresponding to the pore volume between saturation and $100 \mathrm{hPa}$ was added to the plates on which the cylinders were placed.

The following measurements on the soil samples were performed after one month of incubation: concentrations of water soluble and exchangeable $\mathrm{K}, \mathrm{Na}, \mathrm{Ca}$ and $\mathrm{Mg}$, the amount of readily dispersible clay (RDC), water retention, air permeability, shrinkage characteristics and the coefficient of linear extensibility (COLE). The methods are described in detail in the following sections. Also, CROSS, the sodium adsorption ratio $(S A R)$, the potassium adsorption ratio $(P A R)$, exchangeable sodium percentage $(E S P)$, exchangeable potassium percentage $(E P P)$ and $\mathrm{K}: \mathrm{Na}$ ratios were calculated from the concentrations of the cations.

The four soil samples per treatment and soil texture were divided as follows: two randomly selected samples were used for destructive measurements, and the other two samples were kept intact. The amount of readily dispersible clay, CROSS, SAR, PAR, ESP, EPP and K:Na ratios were measured on the former (i.e. destructive measurements). All the other measurements were done on the intact cylindrical samples.

The amount of readily dispersible clay was obtained from turbidity measurements following the method described by Kay and Dexter (1990) and Watts et al. (1996). About $5 \mathrm{~g}$ of air-dry soil was shaken with $125 \mathrm{ml}$ of distilled water in a standardised way. The suspension was allowed to stand for $18 \mathrm{~h}$ for the larger particles to sediment, leaving only colloidal (mostly clay) particles in suspension. $30 \mathrm{ml}$ of 
suspension was taken from the centre of each sample with a pipette and was transferred to a glass turbidity cell. The turbidity was measured using a Hach $2100 \mathrm{~N}$ Laboratory Turbidimeter and recorded in Nephelometric Turbidity Units (NTU).

The cation concentrations were measured on sieved $(<2 \mathrm{~mm})$ soil samples. The water soluble cations $(\mathrm{K}, \mathrm{Na}, \mathrm{Ca}$ and $\mathrm{Mg}$ ) were obtained using the ICP-OES analysis method (Rouessac and Rouessac, 2007). The exchangeable cation concentrations were measured using exchange of the cations with Barium ( $0.1 \mathrm{M} \mathrm{BaCl}_{2}$ solution) from the exchange solution, and $\mathrm{Ca}$ and $\mathrm{Mg}$ were measured by F-AAS, and $\mathrm{K}$ and Na were measured by F-AES (Rouessac and Rouessac, 2007). The sodium adsorption ratio $(S A R)$ was calculated as (Richards, 1954):

$$
S A R=\frac{\mathrm{Na}^{+}}{\sqrt{\frac{\mathrm{Ca}^{2+}+\mathrm{Mg}^{2+}}{2}} .}
$$

The potassium adsorption ratio $(P A R)$ was calculated as (Chen et al., 1983):

$$
P A R=\frac{\mathrm{K}^{+}}{\sqrt{\frac{\mathrm{Ca}^{2+}+\mathrm{Mg}^{2+}}{2}}},
$$

where: the concentrations of water soluble cations in Eqs (2), (3) were measured in soil solution $\left(\mathrm{mmol}_{\mathrm{c}} \mathrm{l}^{-1}\right)$. The EPP and ESP were calculated as (Richards, 1954):

$$
\begin{gathered}
E P P=\frac{\mathrm{K}_{e x}}{C E C} 100, \\
E S P=\frac{\mathrm{Na}_{e x}}{C E C} 100,
\end{gathered}
$$

where: $\mathrm{Na}_{e x}$ and $\mathrm{K}_{e x}$ are concentrations of exchangeable cations $\left(\mathrm{cmol}_{\mathrm{c}} \mathrm{kg}^{-1}\right)$ and $C E C$ is the cation exchange capacity. This was determined by extracting the soils with a 0.1 $\mathrm{M} \mathrm{BaCl}_{2}$ solution, containing $0.03 \mathrm{M}$ Triethanolamine and $0.015 \mathrm{M} \mathrm{HCl}$ and with the $\mathrm{pH}$ adjusted to 8.1 (Rouessac and Rouessac, 2007).

Air permeability was measured using a steady-state method on the intact soil core samples as described by Martínez et al. (2016), at a water content corresponding to a matric suction of $100 \mathrm{hPa}$. The soil at the very edge of the core was carefully pressed to the cylinder walls in order to minimise leakage of air between the soil and the cylinder wall (Ball and Schjønning, 2002). The airflow was recorded when the volumetric flow rate was stabilised at a pressure of $2 \mathrm{hPa}$. Air permeability $\left(k_{a}\right)$ was calculated from the volumetric flow rate and the applied pressure head using Darcy equation, as:

$$
k_{a}=\frac{-Q l_{s} \eta}{\Delta p A_{s}},
$$

where: $Q$ is the volumetric flow rate $\left(\mathrm{m}^{3} \mathrm{~s}^{-1}\right), l_{s}$ is the height of the soil sample (m), $\eta$ is the dynamic air viscosity (Pa s), $\Delta p$ is the difference in air pressure ( $\mathrm{Pa})$ and $A_{s}$ is the crosssectional area of the soil sample $\left(\mathrm{m}^{2}\right)$.

Soil shrinkage and water retention characteristics were measured on the intact soil core samples by monitoring the weight and the height of the samples, and the matric potential in the samples during drying from near saturation (matric suction of $10 \mathrm{hPa}$ ) to air-dry condition was measured using a similar set-up to that described by Boivin et al. (2004). The samples were placed on electronic balances with a precision of $0.01 \mathrm{~g}$. Weight, height (using calibrated displacement transducers with a resolution of $1 \mu \mathrm{m}$ ) and matric suction (up to $c .800 \mathrm{hPa}$, using microtensiometers with ceramic cups of $2 \mathrm{~cm}$ length and $0.2 \mathrm{~cm}$ diameter installed at mid-height of the samples) of the samples were recorded at intervals of $5 \mathrm{~min}$. The measurements were terminated when the sample reached constant weights (Schäffer et al., 2008), which took about one week for our samples. The dry sample volumes were then determined by the plastic-bag method" by means of hydrostatic weighing as described by Boivin et al. (1990) and Schäffer et al. (2008). To obtain an accurate value of the sample volume, the procedure was repeated five times per sample, and the average of the five measurements was used. Finally, the samples were dried in an oven at $105^{\circ} \mathrm{C}$ for $24 \mathrm{~h}$ to obtain the oven-dry weight and to calculate bulk density.

In order to characterise the magnitude of soil volume change after drying, we calculated COLE, described by Gray and Allbrook (2002) as:

$$
C O L E=\left(v_{330 \mathrm{hPa}}-v_{\text {oven-dry }}\right)^{\frac{1}{3}}-1,
$$

where: $v_{330 \mathrm{hPa}}$ is soil volume at a matric suction of $330 \mathrm{hPa}$ (i.e. a value typically considered as field capacity in the US) and $v_{\text {oven-dry }}$ is the soil volume at oven dry condition. Here, we slightly modified Eq. (7) and calculated COLE for different matric suction ranges: $C O L E_{10-330}$ considering volume changes between 10 and $330 \mathrm{hPa}, C O L E_{330-a d}$ considering volume changes between $330 \mathrm{hPa}$ and air-dry condition, and $C O L E_{10 \text {-ad }}$ considering volume changes between $10 \mathrm{hPa}$ and air-dry condition.

The data were analysed using a general linear model (GLM) for a factorial experiment with a completely randomised design, with four replications per treatment. Analyses were made with the MINITAB 16 software. ANOVA (simple effects and multiple comparisons) were done using the least significant difference (LSD) test (Bonferroni method) at the significance level $\mathrm{p}<0.05$. Linear relationships between parameters were determined using regression analysis. 


\section{RESULTS AND DISCUSSION}

Relationships between RDC and $\mathrm{K}$ concentration, $\mathrm{Na}$ concentration, $\mathrm{K}: \mathrm{Na}$ ratio, and cationic indicators (CROSS, $S A R, P A R, E S P$ and $E P P$ ) are shown in Figs 1-3. The results of the analysis of variance (ANOVA) for RDC are shown in supplementary Table S1. The values of RDC measured in our study were in the range of 1100 to 10100 NTU. Although the two soils had similar OC/Clay ratios, RDC was higher in the cl soil ( $45 \%$ clay) than in the si 1 soil (22\% clay) (Figs 1-3). Clay dispersion was high in the cl soil despite the relatively high organic carbon content. Our results are in accordance with data presented by Levy and Torrento (1995) and Etana et al. (2009), who studied soils with different clay contents and observed that RDC was

$\mathrm{a}$

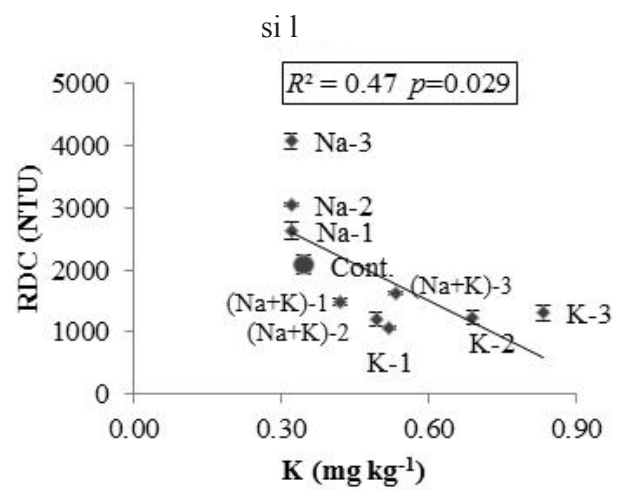

b

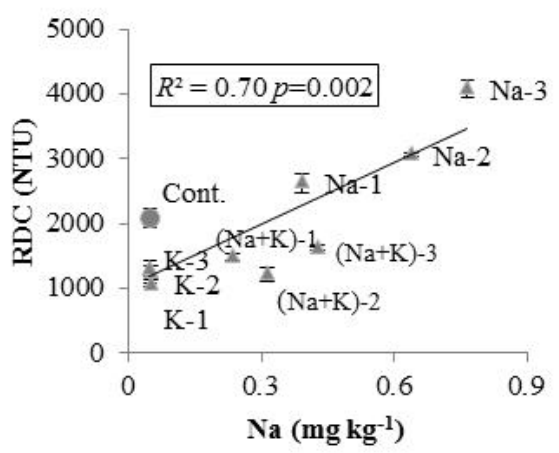

c

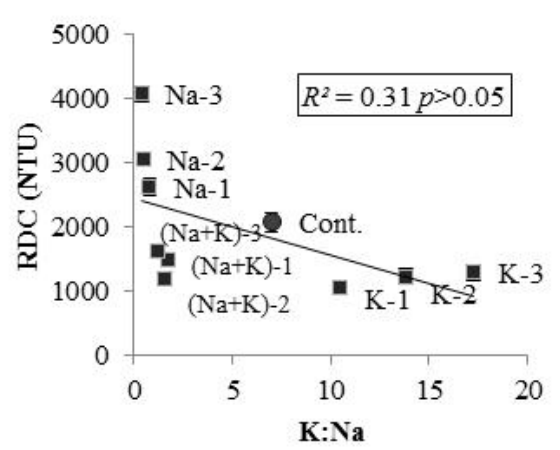

higher in the soils with higher clay contents. Dexter and Czyż (2000) reported that RDC decreased with increasing soil organic carbon content. However, their soils were mostly sandy soils.

For both soils of our study, negative relationships were obtained between RDC and K concentration (Fig. 1a), and positive correlations between RDC and $\mathrm{Na}$ concentration (Fig. 1b). Furthermore, negative correlations were obtained between RDC and K:Na ratios for both soils, although these were not significant (Fig. 1c). Positive correlations were found between RDC and CROSS (Fig. 2a) and RDC and $S A R$ (Fig. 2b), while negative relationships were obtained between RDC and PAR (Fig. 2c). Since the concentrations of $\mathrm{Ca}$ and $\mathrm{Mg}$ did not change between treatments (Table 2), $S A R$ (Eq. (2)) is a function of $\mathrm{Na}$ and $P A R$ (Eq. (3)) is

$\mathrm{cl}$
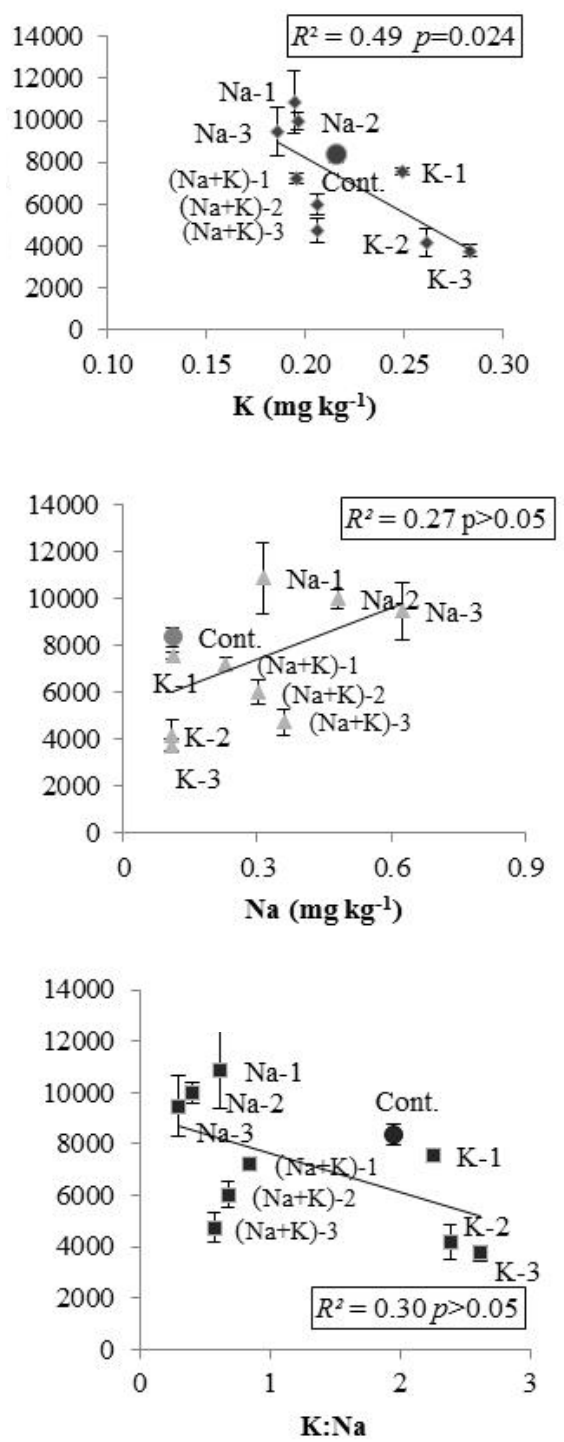

Fig. 1. Amount of readily dispersible clay, RDC in units of NTU, as a function of: a $-\mathrm{K}$ concentration, $\mathrm{b}-\mathrm{Na}$ concentration, $\mathrm{c}-\mathrm{K}: \mathrm{Na}$ ratio, for the silt loam (left) and the clay soil (right). Labels next to the data points indicate treatments (Table 2), cont. indicates control. Note the different scales for RDC for the two soils. 
b
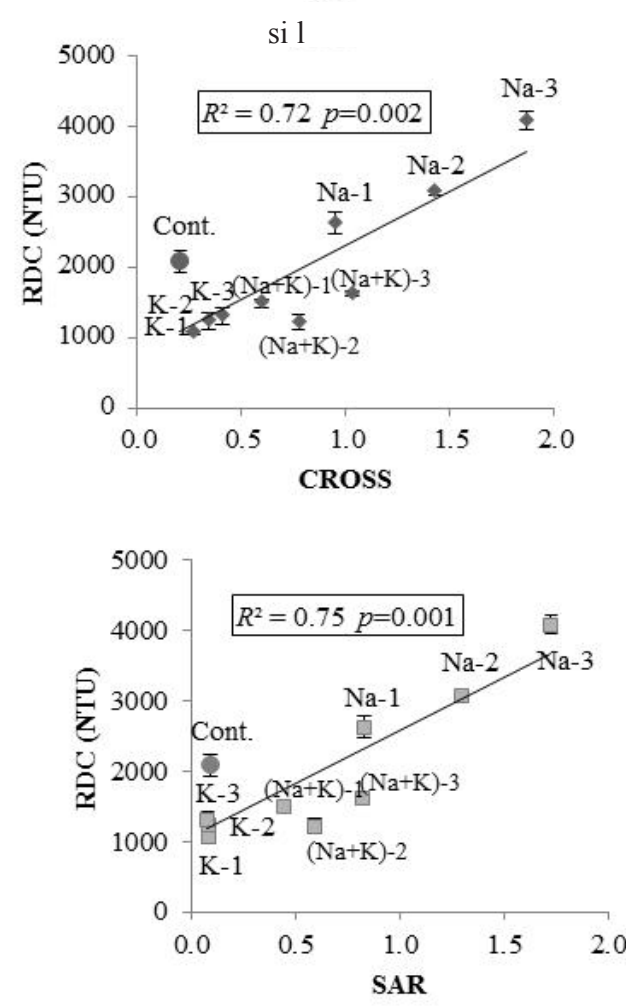

c

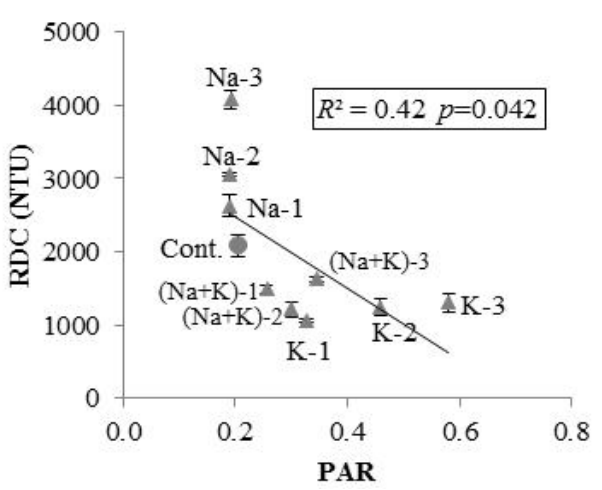

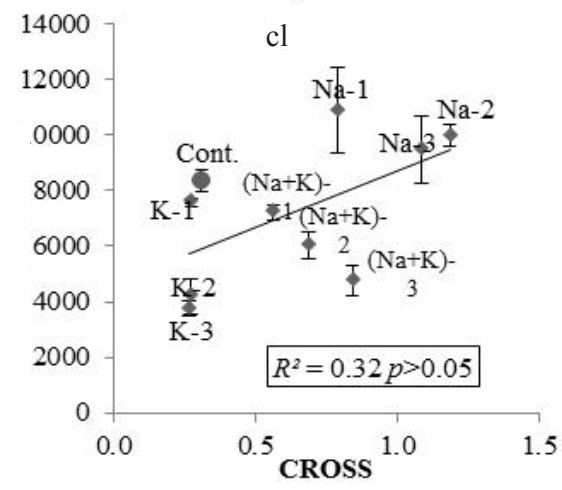
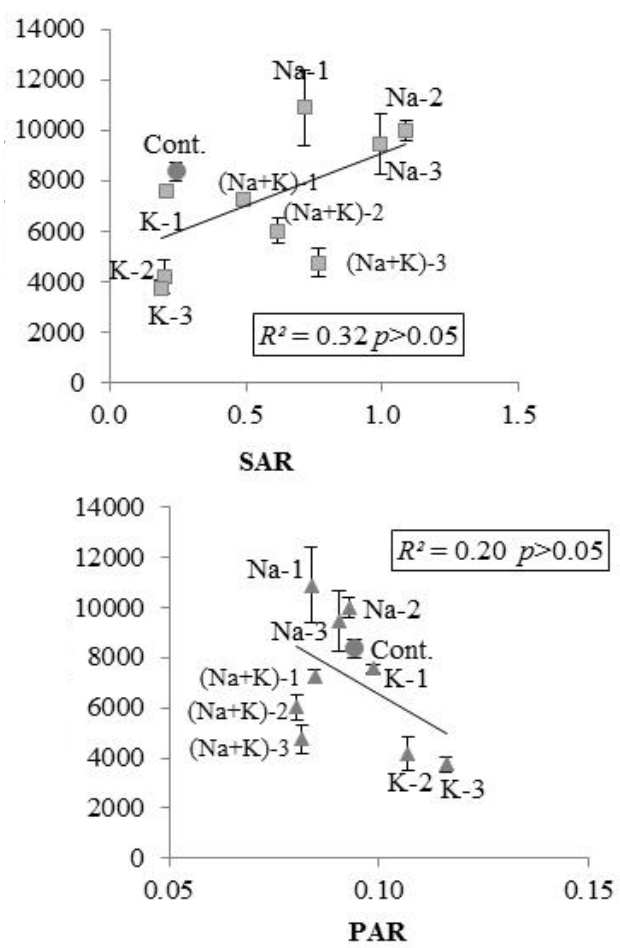

Fig. 2. Amount of readily dispersible clay (RDC) in units of NTU, as a function of the cation ratio of: a - soil structural stability $(C R O S S), \mathrm{b}$ - sodium adsorption ratio $(S A R), \mathrm{c}$ - potassium adsorption ratio (PAR), for the silt loam (left) and the clay soil (right). Labels next to the data points indicate treatments (Table 2), cont. indicates control. Note the different scales for RDC for the two soils.

a function of $\mathrm{K}$ for our soils. Moreover, CROSS (Eq. (1)) is a measure of the combined impact of $\mathrm{Na}$ and $\mathrm{K}$, accounting for the relative dispersive power of $\mathrm{Na}$ and $\mathrm{K}$, respectively (Rengasamy and Marchuk, 2011). Similar to PAR and SAR, negative correlations were found between RDC and $E P P$ (Fig. 3a) and positive correlations were obtained between RDC and ESP (Fig. 3b). We found stronger relationships (i.e. higher $\mathrm{R}^{2}$ values and lower $\mathrm{p}$ values) between $\mathrm{RDC}$ and $\mathrm{Na}$ concentration, as well as $S A R$ and $E S P$ than between $\mathrm{RDC}$ and $\mathrm{K}$ concentration, $P A R$ and $E P P$, indicating that the impact on soil structure was stronger for $\mathrm{Na}$ than for K. What is more, the relationship between RDC and CROSS was similar to that between RDC and $S A R$ (i.e. similar $\mathrm{R}^{2}$ values and similar $p$ values), suggesting the dominance of
$\mathrm{Na}$ over $\mathrm{K}$ in the observed effects. The reason for negative correlations between RDC and PAR $(\mathrm{r}=-0.65$ and $\mathrm{p}=0.04$ for si 1 , and $\mathrm{r}=-0.45$ and $\mathrm{p}=0.19$ for $\mathrm{cl}$ ) is probably related to the mineralogy of our soils. The predominant clay mineral was illite (weathered mica) in both soils (Peters, 1969), and $\mathrm{K}$ was probably fixed. The impact of $\mathrm{K}$ on soil structure in relation to clay mineralogy is discussed in detail is discussed in detail below.

The deleterious effect of $\mathrm{Na}$ on the soil structure has been reported by several researchers. Levy and Torrento (1995) worked on sandy loam and clayey soils and found that increasing exchangeable $\mathrm{Na}$ from 0.5 to $5.5 \%$ led to an increase in the amounts of dispersible clay from 22.2 to 30.4\%. Dexter and Czyż (2000) reported that when $\mathrm{Na}$ is 
a

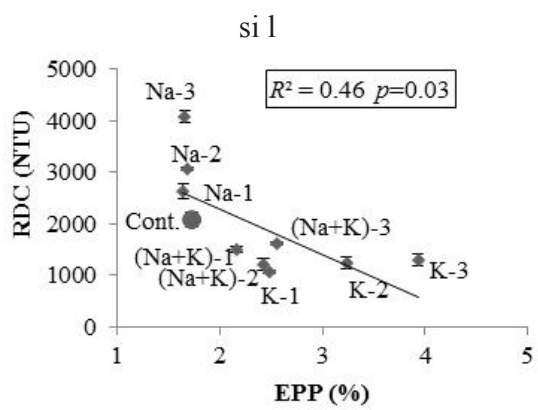

b

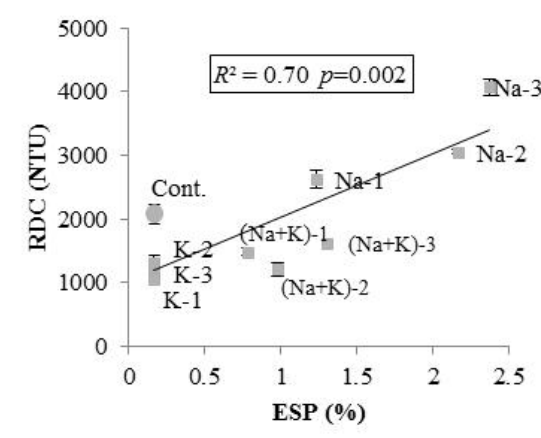

$\mathrm{cl}$
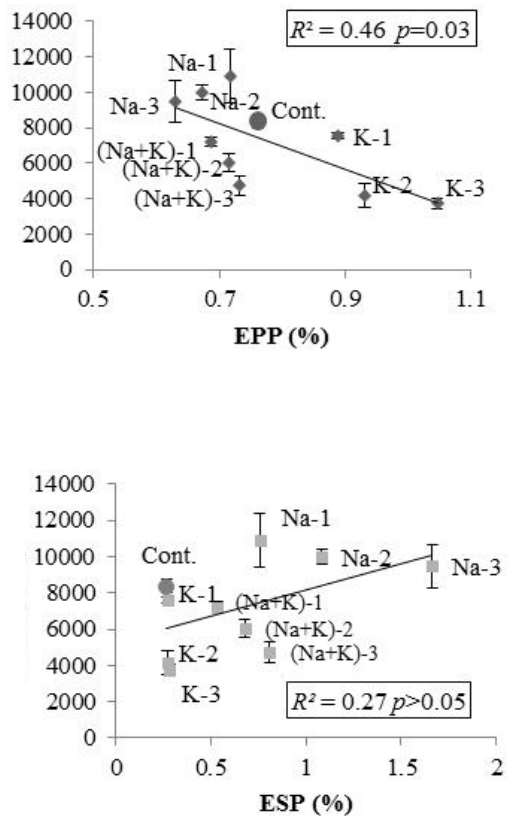

Fig. 3. Amount of readily dispersible clay, RDC in units of NTU, as a function of: a - exchangeable potassium percentage (EPP), and $\mathrm{b}$ - exchangeable sodium percentage $(E S P)$ for the silt loam (left) and the clay soil (right). Labels next to the data points indicate treatments (Table 2), cont. indicates control. Note the different scales for RDC for the two soils.
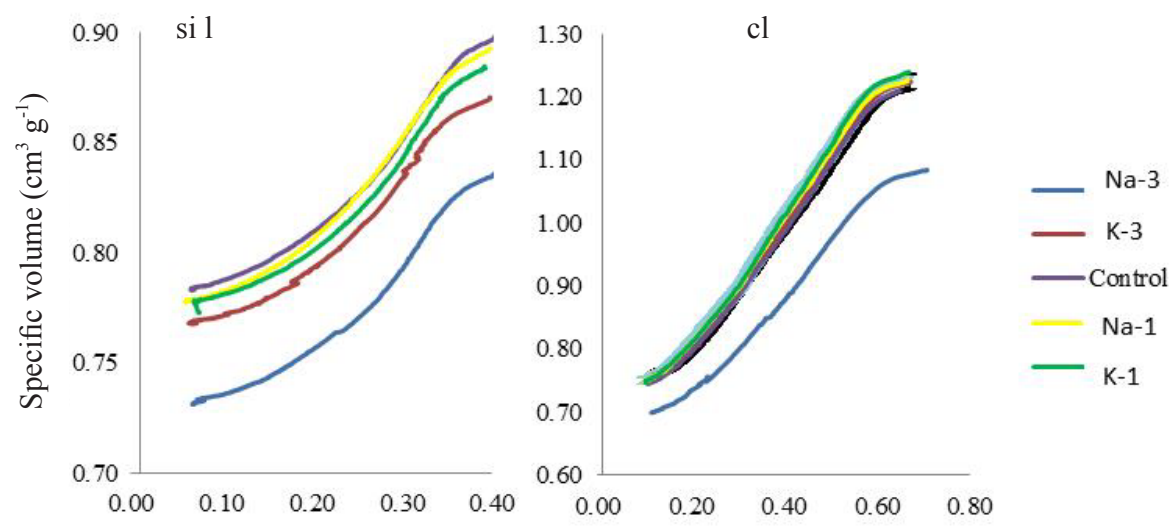

Gravimetric water content $\left(\mathrm{g} \mathrm{g}^{-1}\right)$

Fig. 4. Shrinkage curves for four treatments (Na-1: minimum Na-concentration; Na-3: maximum Na-concentration; K-1: minimum K concentration; and K-3: maximum K concentration; Table 2) and the controls of si 1 and cl.

adsorbed on the surfaces of the clay particles, the particles will repel each other due to the creation of extra negative charges on the clay surfaces, and this will result in clay dispersion when the soil is in water.

The relationships between RDC and cationic indicators were different for the two soils (Figs 1-3). The correlations were stronger (higher $\mathrm{R}^{2}$ value, lower $p$ value) in si $1(22 \%$ clay) than in cl ( $45 \%$ clay). A possible explanation could be the high cation adsorption due to the higher cation exchange capacity (CEC) of the cl (Marchuk and Rengasamy, 2012).
The shrinkage curves - expressed as specific volume against gravimetric water content - of the soils are shown in Fig. 4. Of note, the clay soil exhibited a steeper shrinkage curve than the si 1 . A similar observation was made by Schäffer et al. (2008), who studied soils with different clay contents. In general, a large slope of the shrinkage curve indicates a weak soil structure (Schäffer et al., 2008). This would explain why RDC was higher in cl than in si 1 (Figs 1-3). 
Little effects of cationic treatment compositions on the shrinkage characteristics, except for the treatment ' $\mathrm{Na}-3$ ' containing the maximum $\mathrm{Na}$ concentration was observed (Table 2) for both soils (Fig. 4). The high Na concentration resulted in a substantial decrease in specific volume corresponding to a decrease in total porosity, presumably due to dispersed clay particles. This effect is similar to that observed by Sou/Dakouré et al. (2013), who irrigated different plots of a sandy loam soil from Burkina Faso with tap water and wastewater containing a high concentration of $\mathrm{Na}$, and found that shrinkage curves from irrigated plots with wastewater (high Na concentrations) showed the lowest specific volume due to structural collapse created by the adverse effects of $\mathrm{Na}$ on the soil.

The coefficients of linear extensibility (COLE) for three matric suction ranges are summarised in Table 3. COLE was larger for cl than for si 1, which is associated with the higher clay content of cl. Gray and Allbrook (2002) worked on twenty-four soil horizons and series from New Zealand with clay contents in the range of 13 to $86 \%$, and found a significant correlation between COLE and clay content in non-allophane samples. Smith et al. (1985) studied 66 samples from 32 soil profiles in Israel and obtained a high correlation coefficient between COLE and clay content as well.

The lowest values of COLE belonged to the 'Na-3' treatment containing the maximum $\mathrm{Na}$ concentration (Table 3). The difference in COLE between the 'Na-3' and the other treatments was especially pronounced in the $\mathrm{cl}$ soil. These results indicate that the shrinkage capability of soil decreased at high $\mathrm{Na}$ concentration due to soil structural collapse caused by clay dispersion.

The water retention curves of the soils are presented in Fig. 5. The clay soil showed higher water retention (higher water content at any given matric suction) than si 1 due to the higher clay content. The one-month incubation with treatment solutions had generally no or only little effect on water retentions in both soils. The only exception was the treatment with the maximum $\mathrm{Na}$ concentration, i.e. the 'Na-3' treatment, which increased water retention (Fig. 5). A possible explanation could be that clay dispersion decreased average soil pore size that increased water retention (Fig. 5). This is consistent with the observed reduction in air permeability with increasing RDC (Fig. 6). Our results are further in agreement with the findings of Duy Nang (2012). He studied plant available water on a saline-sodic Australian soil profile as affected by leaching with different solutions and found the highest water retention in the samples with maximum clay dispersion. Duy Nang explained that this was attributable to a shift toward smaller pores because of clay dispersion.

Soil texture, type of cations and concentration of cations in the treatment solutions had significant impacts on $k_{\mathrm{a}}$. Results of the analysis of variance (ANOVA) for $k_{\mathrm{a}}$ are shown in supplementary Table S1. Since the individual samples had slightly different initial air permeabilities, we calculated the ratio of final (after incubation) to initial $k_{\text {a }}$ (before incubation), $k_{a}$-final $/ k_{a}$-initial, as a measure of the change in $k_{\mathrm{a}}$. The values of $k_{a}$-final $/ k_{a}$-initial were $\geq 1$ for all

Table 3. Coefficient of linear extension (COLE) for three matric suction ranges for selected treatments (Table 2) and the control

\begin{tabular}{|c|c|c|c|c|}
\hline \multirow{2}{*}{ Soil } & \multirow{2}{*}{$\begin{array}{c}\text { Treatment } \\
\text { type }\end{array}$} & \multicolumn{3}{|c|}{ COLE } \\
\hline & & $10-330 \mathrm{hPa}$ & $330 \mathrm{hPa}$ - air-dry & $10 \mathrm{hPa}$ - air-dry \\
\hline \multirow{5}{*}{ si 1} & $\mathrm{Na}-1$ & $0.70 \mathrm{~A}$ & $0.98 \mathrm{~A}$ & $1.33 \mathrm{~A}$ \\
\hline & $\mathrm{Na}-3$ & $0.66 \mathrm{AB}$ & $0.93 \mathrm{~A}$ & $1.28 \mathrm{AB}$ \\
\hline & $\mathrm{K}-1$ & $0.65 \mathrm{AB}$ & $0.94 \mathrm{~A}$ & $1.27 \mathrm{AB}$ \\
\hline & K-3 & $0.61 \mathrm{~B}$ & $0.93 \mathrm{~A}$ & $1.25 \mathrm{~B}$ \\
\hline & Control & $0.74 \mathrm{~A}$ & $0.96 \mathrm{~A}$ & $1.34 \mathrm{~A}$ \\
\hline \multirow{5}{*}{$\mathrm{cl}$} & $\mathrm{Na}-1$ & $1.44 \mathrm{~A}$ & $2.22 \mathrm{~A}$ & $2.64 \mathrm{~A}$ \\
\hline & $\mathrm{Na}-3$ & $1.15 \mathrm{~B}$ & $2.04 \mathrm{~A}$ & $2.37 \mathrm{~A}$ \\
\hline & $\mathrm{K}-1$ & $1.28 \mathrm{AB}$ & $2.36 \mathrm{~A}$ & $2.68 \mathrm{~A}$ \\
\hline & $\mathrm{K}-3$ & $1.22 \mathrm{AB}$ & $2.35 \mathrm{~A}$ & $2.65 \mathrm{~A}$ \\
\hline & Control & $1.37 \mathrm{AB}$ & $2.23 \mathrm{~A}$ & $2.61 \mathrm{~A}$ \\
\hline
\end{tabular}

Values followed by different letters in the same column are significantly different $(\mathrm{p}<0.05)$. 

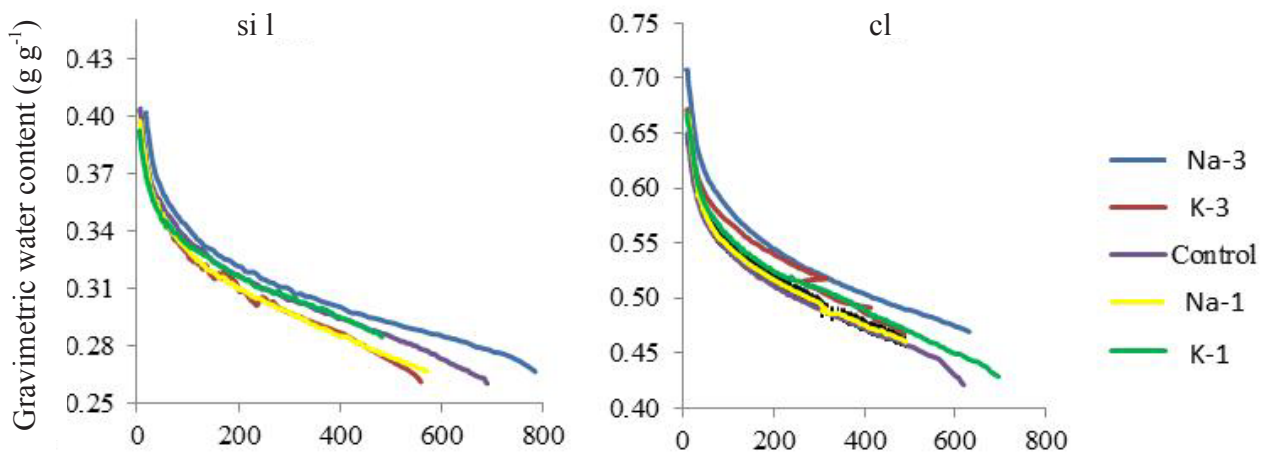

Matric suction $(\mathrm{hPa})$

Fig. 5. Water retention curves for four treatments (Na-1: minimum Na-concentration; Na-3: maximum Na-concentration; K-1: minimum K concentration; and K-3: maximum K concentration; Table 2) and the controls of si 1 and cl.

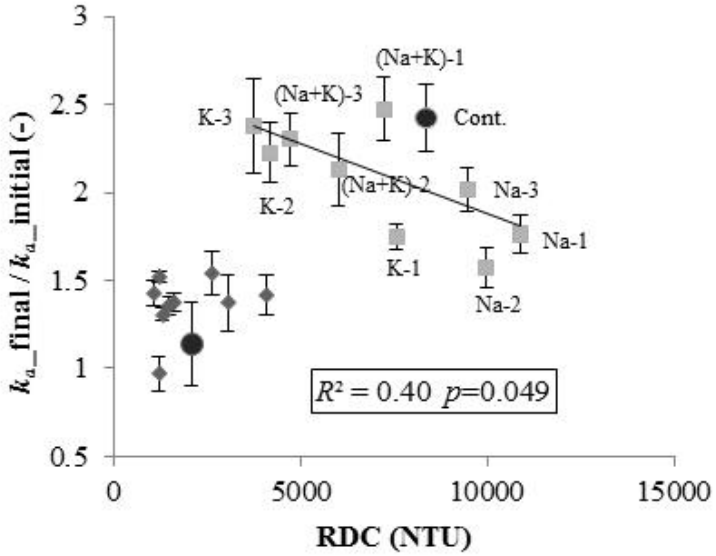

Fig. 6. The ratio of air permeability before incubation to air permeability after incubation, $k_{\text {afinal }} k_{a_{-} \text {initial }}$, as a function of the amount of readily dispersible clay (RDC) expressed in units of NTU. si 1: rhombi symbols; cl: square symbols. Labels next to the data points indicate treatments (Tables 2 and 3), cont. indicates control.

samples in both soils (Fig. 6), indicating that $k_{\mathrm{a}}$ increased after incubation for all treatments including the control (no treatment solution). This observation is attributed to the effect of moderate drying and wetting on the soil structure. For example, Arthur et al. (2012) studied three soils with sandy loam texture from Denmark and found that $k_{\mathrm{a}}$ increased remarkably (from $<2 \mu \mathrm{m}^{2}$ to $15-25 \mu \mathrm{m}^{2}$ ) with increasing numbers of drying-wetting cycles. They demonstrated that wetting and drying cycles increased soil void ratio, and this had positive effects on $k_{\mathrm{a}}$.

A significant negative correlation $(r=-0.63, p=0.049)$ was found between $k_{a-\text { final }} / k_{\text {a-initial }}$ and RDC for $\mathrm{cl}$, but not si 1 . The decrease in $k_{a-\text { final }} / k_{\text {a-initial }}$ with increasing $\mathrm{RDC}$ in cl could be because macropores were filled (i.e. clogged) with dispersed clay particles. Arienzo et al. (2012) percolated solutions with sodium adsorption ratios (SAR) of 5-40 through an Australian clay loam soil, and observed that relative hydraulic conductivity decreased with increasing
$S A R$. The fact that we did not find a relationship between $k_{a-\text { final }} / k_{a-\text { initial }}$ and RDC in si 1 is probably related to the generally lower values of RDC (Figs 1-3)

The initial $k_{a}$ was on average larger in si 1 than in $\mathrm{cl}$, but the ratio of $k_{a-\text { final }} / k_{\text {a-initial }}$ was lower in si 1 than in $\mathrm{cl}$, which could be associated to the lower clay content in si 1 compared with cl. Gregory et al. (2009) studied 15 soils from England with clay content from 0.078 to $0.727 \mathrm{~g} \mathrm{~g}^{-1}$ and applied a wetting-drying cycle, including wetting at a matric suction of $5 \mathrm{hPa}$ on a tension table for $24 \mathrm{~h}$, drying at $40^{\circ} \mathrm{C}$ for $24 \mathrm{~h}$ and re-equilibrating at a matric suction of $50 \mathrm{hPa}$ on a tension table. They found that wetting and drying cycles increased the void ratio of the soils only when the clay content was greater than $0.26 \mathrm{~g} \mathrm{~g}^{-1}$. This could explain why the values of $k_{a-\text { final }} k_{\text {a-initial }}$ were found to be larger for the $\mathrm{cl}$ ( $45 \%$ clay) than for the si 1 (22\% clay). McNeal et al. (1968), in their study of soils with variable clay contents but similar clay mineralogy, also observed that changes of soil structure caused by chemical or environmental factors were greater in soils with higher clay content.

The results with regard to the impact of $\mathrm{K}$ on soil structure presented in this paper are apparently in contradiction to the findings presented in Part I of this series of papers (Farahani et al., 2018). Here, we demonstrate that clay dispersion was little affected by $\mathrm{K}$ and tended to decrease with increasing $\mathrm{K}$ concentration (Fig. 1), while we found that $\mathrm{K}$ strongly increased clay dispersion in Part I of our work (Fig. 1 in Farahani et al., 2018). The si 1 soil used in this paper had a similar texture as the soil used in Part I, and the experimental procedure (the addition of monovalent cations in treatment solutions and incubation for one month) and treatment concentrations ( $\mathrm{K}$ in the range of 0-60 $\mathrm{mmol}_{\mathrm{c}}$ $1^{-1}$ ) were similar in both studies. However, the soils used in this paper were from Switzerland, while the soil used in Part I was an Iranian soil. Although the soils in the two studies had similar clay contents, they had different clay mineralogy. The dominant clay type was mica for both the Swiss and Iranian soils. However, the dominant clay 
mineral in the Iranian soil was muscovite (Haghnia, 1982), while illite was the dominant clay mineral in the Swiss soils (Peters, 1969). Below, we will demonstrate that the different impacts of $\mathrm{K}$ on soil structure observed in our studies are related to clay-mineral differences in the soils.

Illite has an interlayer $\mathrm{K}$ deficiency in comparison with muscovite. Hence, some of the added $\mathrm{K}$ ions can be adsorbed between the clay layers of illite, i.e. illite can fix $\mathrm{K}$. In contrast, if excess $\mathrm{K}$ is added to a soil containing muscovite, the added $\mathrm{K}$ ions cannot be adsorbed between the clay layers. Other researchers have demonstrated that hydrous micas and all clay minerals that have been called 'illites' can be fully or partly regenerated to muscovite by the addition and fixation of $\mathrm{K}$ ions (Carroll, 1959). The different interactions of muscovite and illite, respectively, with $\mathrm{K}$ have implications for the behaviour of clay in soil, and, by extension, for soil structural form and stability.

In our study, we applied $\mathrm{K}$ in the range of 0-60 $\mathrm{mmol}_{\mathrm{c}}$ $\mathrm{I}^{-1}$, and the results indicated that in the Iranian soil containing muscovite, $\mathrm{K}$ ions were not fixed and had a negative effect on soil structure (Part I of this series of papers; Farahani et al. 2018), whereas in the Swiss soils containing illite, $\mathrm{K}$ ions were fixed, which prevented the negative effects of $\mathrm{K}$ on soil structure (this paper). We hypothesise that higher $\mathrm{K}$ concentrations have negative effects on soil structure in soils containing illite when the amount of $\mathrm{K}$ exceeds the ' $\mathrm{K}$ fixing potential' of illite. According to Chen et al. (1983), Shainberg et al. (1987) and Marchuk et al. (2013), the behaviour of $\mathrm{K}$ depends on the cation exchange capacity of the minerals and on the concentration of $\mathrm{K}$. In their work, Chen et al. (1983) applied 0-1000 $\mathrm{mmol}_{\mathrm{c}} \mathrm{l}^{-1}$ $\mathrm{K}$ to soils containing a mixture of smectite and illite, and demonstrated that hydraulic conductivity decreased sharply when the applied K concentration was high. Marchuk et al. (2013) found that clay dispersion was lower in a soil with minerals (such as smectite and vermiculite) with high exchange capacity $\left(120-150 \mathrm{cmol}_{\mathrm{c}} \mathrm{kg}^{-1}\right)$ that have a fixation affinity for $\mathrm{K}$ ions. Hence, for micaceous clay minerals, the negative effect of $\mathrm{K}$ on soil structure would decrease in the sequence muscovite $>$ illite $>$ vermiculite. This would indicate that the risk of negative effects from $\mathrm{K}$ is highest in unweathered soils. Further studies should be undertaken to test these hypotheses.

\section{CONCLUSIONS}

The results obtained the negative effect of $\mathrm{Na}$ on soil structure.

1. The amount of readily dispersible clay increased with increasing $\mathrm{Na}$ concentration, cation ratio of soil structural and sodium adsorption ratio, suggesting that these are good indicators for assessing the impact of $\mathrm{Na}$ on the structure of the studied soils.
2. The treatment with the maximum $\mathrm{Na}$ concentration resulted in the highest water retention and in the lowest shrinkage capacity. This effect was associated with high amounts of readily dispersible clay, resulting in a shortrange migration of clay and the clogging of soil pores.

3. Air permeability generally increased during incubation due to moderate wetting and drying cycles, but the increase was negatively correlated with readily dispersible clay.

4. Readily dispersible clay decreased with increasing $\mathrm{K}$. It was in contradiction to the findings in Part I, where readily dispersible clay increased with increasing $\mathrm{K}$ concentration and $\mathrm{K}$ had negative effects on soil structure. We demonstrate that this is attributable to the different clay mineralogy of the studied soils (muscovite in Part I and illite in this paper).

\section{ACKNOWLEDGEMENTS}

The stay at Agroscope (Zürich, Switzerland) of the first author (Elham Farahani) was made possible through a scholarship from the Ministry of Science, Research and Technology of Iran, which is gratefully acknowledged. We thank Marlies Sommer and Diane Bürge (Agroscope) for their help with the laboratory measurements.

Conflict of interest: The Authors do not declare conflict of interest.

\section{REFERENCES}

Arienzo M., Christen E.W., Jayawardane N.S., and Quayle W.C., 2012. The relative effects of sodium and potassium on soil hydraulic conductivity and implications for winery wastewater management. Geoderma, 173-174, 303-310.

Arienzo M., Christen E.W., Quayle W., and Kumar A., 2009. A review of the fate of potassium in the soil-plant system after land application of wastewaters. J. Hazard. Mater., $164,415-422$.

Arthur E., Schjønning P., Moldrup P., and de Jonge L.W., 2012. Soil resistance and resilience to mechanical stresses for three differently managed sandy loam soils. Geoderma, 173-174, 50-60.

Ball B.C., 1981. Pore characteristics of soils from two cultivation experiments as shown by gas diffusivities and permeabilities and air-filled porosities. J. Soil Sci., 32,483-498.

Ball B.C. and Schjønning P., 2002. Air permeability. In: Methods of Soil Analysis (Eds Dane J.H., Topp G.C.). Part 4. SSSA, Madison, 1141-1158 (Al).

Blackwell P.S., Ringrose-Voase A.J., Jayawardane N.S., Olsson K.A., McKenzie D.C., and Mason W.K., 1990. The use of air-filled porosity and intrinsic permeability to air to characterize structure of macropore space and saturated hydraulic conductivity of clay soils. J. Soil Sci., 41, 215-228.

Boivin P., Brunet D., and Gascuel-Odoux C., 1990. Densité apparente d'échantillon de sol: méthode de la poche plastique. Bulletin du Groupe Français d'Humidimétrie Neutronique et des Techniques Associés, 28, 59-71. 
Boivin P., Garnier P., and Tessier D., 2004. Relationship between clay content, clay type, and shrinkage properties of soil samples. Soil Sci. Soc. Am. J., 68, 1145-1153.

Braudeau E., Costantini J.M., Bellier G., and Colleuille H., 1999. New device and method for soil shrinkage curve measurement and characterization. Soil Sci. Soc. Am. J., $63,525-535$

Carroll D., 1959. Ion exchange in clays and other minerals. Geol. Soc. Am. Bull., 70, 749-779.

Chaudhari S.K. and Somawanshi R.B., 2004. Unsaturated flow of different quality irrigation waters through clay, clay loam and silt loam soils and its dependence on soil and solution parameters. Agric. Water Manag., 64, 69-90.

Chen Y., Banin A., and Borochovitch A., 1983. Effect of potassium on soil structure in relation to hydraulic conductivity. Geoderma, 30, 135-147.

Dexter A.R. and Czyż E.A., 2000. Effects of soil management on the dispersibility of clay in a sandy soil. Int. Agrophysics, 14, 269-272.

Duy Nang N., 2012. Plant availability of water in soils being reclaimed from the saline-sodic state. Ph.D. Thesis, University of Adelaide, Australia.

El Swaify S.A., Ahmed S., and Swindale L.D., 1970. Effects of adsorbed cations on physical properties of tropical red and tropical black earths. J. Soil Sci., 21, 188-198.

Emami H., Astaraei A.R., Fotovat A., and Khotabaei M., 2014. Effect of soil conditions on cation ratio on soil structural stability, structural stability indicators in a sodic soil, and on dry weight of Maize. Arid Land Res. Manag., 28, 325-339.

Etana A., Rydberg T., and Arvidsson J., 2009. Readily dispersible clay and particle transport in five Swedish soils under long-term shallow tillage and mouldboard ploughing. Soil Till. Res., 106, 79-84.

Farahani E., Emami H., Keller T., Fotovat A., and Khorasani R., 2018. Impact of monovalent cations on soil structure. Part I. Results of an Iranian soil. Int. Agrophys., 32, 57-67.

Frenkel H. and Rhoades J.D., 1978. Effects of dispersion and swelling on soil hydraulic conductivity. J. Testing Evaluation, JTEVA, 6, 60-65.

Gee G.W. and Bauder J.W., 1986. Particle-size distribution. In: Methods of Soil Analysis. Part 1. Physical and Mineralogical Methods (Ed. A. Klute), Agron. Monog., 9, 384-411 ASA/ SSSA, Madison, WI, USA.

Gray C.W. and Allbrook R., 2002. Relationships between shrinkage indices and soil properties in some New Zealand soils. Geoderma, 108, 287-299.

Gregory A.S., Watts C.W., Griffiths B.S., and Hallett P.D., 2009. The effect of long-term soil management on the physical and biological resilience of a range of arable and grassland soils in England. Geoderma, 153,172-185.

Haghnia Gh.H., 1982. Clay mineral studies on some selected soils of Mashhad plain (in Persian). Iranian J. Agric. Sci., 13, 1-16.

Iversen B.V., Schjønning P., Poulsen T.G., and Moldrup P., 2001. In situ, on-site and laboratory measurements of soil air permeability: boundary conditions and measurement scale. Soil Sci., 166, 97-106.

Johannes A., Matter A., Schulin R., Weisskopf P., Baveye P.G., and Boivin P., 2017. Optimal organic carbon values for soil structure quality of arable soils. Does clay content matter? Geoderma, 302, 14-21.

Kay B.D., 1990. Rates of change of soil structure under different cropping systems. Adv. Soil Sci., 12, 1-52.

Kay B.D. and Dexter A.R., 1990. Influence of aggregate diameter, surface area and antecedent water content on the dispersibility of clay. Can. J. Soil Sci., 70, 655-671.

Levy G.J. and Torrento J.R., 1995. Clay dispersion and macroaggregate stability as affected by exchangeable potassium and sodium. Soil Sci., 160, 352-358.

Marchuk A. and Rengasamy P., 2012. Threshold electrolyte concentration and dispersive potential in relation to CROSS in dispersive soils. Soil Res., 50, 473-481.

Marchuk A., Rengasamy P., and McNeill A., 2013. Influence of organic matter, clay mineralogy and $\mathrm{pH}$ on the effects of CROSS on soil structure is related to the zeta potential of the dispersed clay. Soil Res., 51, 34-40.

Martinez I., Chevert A., Weisskopf P., Sturny W.G., Rek J., and Keller T., 2016. Two decades of no-till in the Oberacker long-term field experiment: Part II. Soil porosity and gas transport parameters. Soil Till. Res., 163, 130-140.

McNeal B.L., Layfield D.A., Norvell W.A., and Rhoades J.D., 1968. Factors influencing hydraulic conductivity of soils in the presence of mixed-salt solutions. Soil Sci. Soc. Am. Proc., 32, 187-190.

Menneer j. C., McLay C.D.A., and Lee R., 2001. Effects of sodium-contaminated wastewater on soil permeability of two New Zealand soils. Aust. J. Soil. Res., 39, 877-891.

Naderi-Boldaji M., Weisskopf P., Stettler M., and Keller T., 2016. Predicting the relative density from on-the-go horizontal penetrometer measurements at some arable top soils in Northern Switzerland. Soil Till. Res., 159, 23-32.

Peters T., 1969. Tonmineralogie einiger Glazialablagerungen im schweizerischen Mittelland. Ecologae Geol. Helv., 62, 517-525.

Quirk J.P. and Schofield R.K., 1955. The effect of electrolyte concentration on soil permeability. J. Soil Sci., 6,163-178.

Rengasamy P., 2002. Clay dispersion. In: Soil Physical Measurement and Interpretation for Land Evaluation (Eds B.M. McKenzie et al.). CSIRO Publishing, Melbourne.

Rengasamy P., 2006. World salinization with emphasis on Australia. J. Exp. Bot., 57, 1017-1023.

Rengasamy P. and Marchuk A., 2011. Cation ratio of soil structural stability (CROSS). Soil Res., 49, 280-285.

Richards L.A., 1954. Diagnosis and Improvement of Saline and Alkali Soils. USDA Hand book. 60, 84.

Robbins C.W., 1984. Sodium adsorption ratio-exchangeable sodium percentage relationships in a high potassium salinesodic soil. Irrigation Sci., 5, 173-179.

Rouessac F. and Rouessac A., 2007. Chemical analysis modern instrumentation methods and techniques. Atrium, Southern Gate, Chichester, West Sussex, England.

Schäffer B., Schulin R., and Boivin P., 2008. Changes in shrinkage of restored soil caused by compaction beneath heavy agricultural machinery. Eur. J. Soil Sci., 59, 771-783.

Schäffer B., Schulin R., and Boivin P., 2013. Shrinkage properties of repacked soil at different states of uniaxial compression. Soil Sci. Soc. Am. J., 77, 1930-1943.

Shainberg I., Keren R., Alperovitch N., and Goldstein D., 
1987. Effect of exchangeable potassium on the hydraulic conductivity of smectite-sand mixtures. Clays Clay Miner., 35(4), 305-310.

Shainberg I. and Letey J., 1984. Response of soils to sodic and saline conditions. Hilgardia, 52, 1-57.

Smiles D.E., 2006. Sodium and potassium in soils of the Murray - Darling Basin: a note. Aust. J. Soil Res., 44, 727-730.

Smith C.W., Hadas A., Dan J., and Koyumdjisky H., 1985. Shrinkage and Atterberg limits in relation to other properties of principal soil types in Israel. Geoderma, 35, 47-65.

Sou/Dakoure M.Y., Mermoud A., Yacouba H., and Boivin P., 2013. Impacts of irrigation with industrial treated wastewater on soil properties. Geoderma, 200-201, 31-39.

Subba Rao A. and Rao C.S., 1996. Potassium status and crop response to potassium on the soils of agro-ecological regions of India. IPI Res. Topics No. 20, 1-57, International Potash Institute, Basel, Switzerland.

Sumner M.E., 1993. Sodicsoils: New perspectives. Aust. J. Soil Res., 31, 683-750.

Walkley A. and Black I.A., 1934. An Examination of Degtjareff method for determining soil organic matter and a proposed modification of the chromic acid titration method. Soil Sci., 37, 29-37.

Watts C.W., Dexter A.R., Dumitru E., and Canarache A., 1996. Structural stability of two Romanian soils as influenced by management practices. Land Degrad. Dev., 7, 217-238. 